\title{
DEMOKRASI VIRTUAL DAN PERANG SIBER DI MEDIA SOSIAL: PERSPEKTIF NETIZEN INDONESIA
}

\author{
Iswandi Syahputra \\ Program Studi Ilmu Komunikasi Fakultas Sosial dan Humaniora Universitas Islam Negeri \\ (UIN) Sunan Kalijaga, Yogyakarta, Jln. Marsda Adi Sucipto Yogyakarta, Indonesia, \\ No. Tlp. +62 274585300 , Fax. +62 274586117 \\ Email: ditra73@yahoo.com
}

\begin{abstract}
Several hate speech which spread in social media activity aroused because of freedom of speech euphoria in a democratic nation. Those hate speech had effectively used as a negative campaign during election. This study aims to analyze hate speech and cyber war in social media. The method used is qualitative with data retrieval through in-depth interviews of netizens as opinion makers in social media, document studies and literature studies relevant to the research. The study found that cyber warfare in social media has formed two netizen polarizations. The polarization can be identified as conservative and liberal groups. Both groups are actively producing discourse, opinion, information, issues and rumors through social media. This study has implications for the change or shift of opinion leader concept on the theory of two step communication. The concept of opinion maker in the new media tradition that emerges today allows anyone anonymously to become opinion leaders.
\end{abstract}

Keywords: Hate Speech, Cyber War, Social Media, Netizens.

\begin{abstract}
Abstrak
Ujaran kebencian yang menyebar dalam aktivitas di media sosial muncul karena eforia kebebasan menyampaikan pendapat dalam suatu negara yang demokratis. Ujaran kebencian tersebut efektif digunakan sebagai kampanye negatif pada saat pemilihan umum. Penelitian ini bertujuan untuk menganalisis ujaran kebencian dan perang siber di media sosial. Metode yang digunakan adalah kualitatif dengan pengambilan data melalui wawancara mendalam terhadap netizen sebagai opinion maker di media sosial, studi dokumen dan studi literatur yang relevan dengan penelitian. Penelitian ini menemukan bahwa perang siber di media sosial telah membentuk dua polarisasi netizen. Polarisasi tersebut dapat diidentifikasi sebagai kelompok konservatif dan kelompok liberal. Kedua kelompok tersebut aktif memproduksi wacana, opini, informasi, isu dan rumors melalui media sosial. Penelitian ini memberikan implikasi pada perubahan atau pergeseran konsep opinion leader pada teori two step communication. Konsep opinion maker dalam tradisi media baru yang muncul saat ini memungkinkan siapa saja secara anonim menjadi opinion leader.
\end{abstract}

Kata kunci: Ujaran Kebencian, Perang Siber, Media Sosial, Netizen.

\section{Pendahuluan}

Survey yang dilakukan oleh Asosiasi Penyelenggara Jasa Internet Indonesia (APJII) bulan November tahun 2016 (APJII, 2016) menunjukkan bahwa sebanyak 129,2 juta $(97,4 \%)$ dari total pengguna internet di Indonesia menjadikan media sosial sebagai jenis konten yang paling sering diakses. Data tersebut menunjukkan bahwa setengah lebih penduduk Indonesia atau 129,2 juta dari 256,2 juta penduduk Indonesia menggunakan media sosial sebagai konten yang paling sering diakses untuk memenuhi segala kebutuhan informasi mereka. Kehadiran media sosial yang digunakan sebagai sumber informasi khalayak tersebut telah mengubah pola interaksi sosial atau interaksi antar individual. 
Menurut Simangunsong (2017), keberadaan media sosial seharusnya dipergunakan untuk memperkuat hubungan atau mencari hubungan dengan orang lain. Namun, aktivitas individu di media sosial cenderung seenaknya dalam mengeluarkan pernyataan. Beberapa netizen di media sosial bahkan saling menyerang,melecehkan atau mencederai identitas yang sudah dimiliki oleh individu lainnya. Hal ini menunjukkan adanya kelemahan individu dalam literasi media sosial itu sendiri.

Perubahan pola interaksi antar individu tersebut disebabkan karena karakteristik media sosial memungkinkan setiap penggunanya tidak saja mengkonsumsi informasi, tetapi juga memproduksi informasi sekaligus mendistribusikan informasi tersebut. Karakteristik baru ini memungkinkan siapa saja yang aktif di media sosial dapat masuk dan terlibat menjadi konsumen, sekaligus produsen informasi. Bahkan setiap aktivis atau pengguna media sosial berperan sebagai distributor pesan (Weeks and Holbert, 2013). Beberapa ahli menyebut media sosial merupakan faktor yang menentukan perubahan dramatis dari struktur komunikasi yang mapan selama ini. Ini merupakan era beralihnya komunikasi massa ke era komunikasi interaksi berbasis internet (Khang, Ki and Ye, 2012).

Riset yang dilakukan oleh Prabowo dan Arofah (2017) menunjukkan bahwa persaingan antar jenis media sosial berlangsung dengan ketat. Kondisi ini akan mengarah pada segmentasi pengguna media sosial di masa mendatang. Penelitian tersebut juga menggambarkan bahwa masingmasing media sosial memiliki kekuatannya masing-masing. Media sosial yang mampu mengakomodasi sifat agresif, progresif serta menampilkan self performance akan menarik minat penggunanya. Sedangkan media sosial yang kurang mengenal karakter konsumennya akan ditinggalkan. Relasi antara media dengan individu tidak lagi linier (satu arah). Relasi individu dengan media sosial juga membentuk perilaku (budaya) baru di kalangan penggunanya, seperti budaya narcicism. Budaya narcicism tersebut semakin meningkat di masyarakat seiring dengan dengan bertumbuhnya media sosial

Karkateristik media sosial tersebut memungkinkan setiap orang dapat berbagi informasi pada khalayak atau pada siapa saja yang dikehendakinya. Dan setiap orang di media sosial punya otoritas memilih dan membuat sendiri opini yang mereka inginkan. Di Indonesia, kemungkinan tersebut semakin lebih leluasa karena didorong dan disokong oleh iklim demokrasi yang menjamin setiap orang bebas berpendapat dan menyampaikan opininya di media sosial secara bebas. Masyarakat online (netizen) dan media sosial dapat berperan sebagai agen sosial dan perubahan politik (Gordon, 2017). Karakteristik media sosial yang spesifik dalam iklim demokrasi yang bebas tersebut, aktivitas media sosial di Indonesia menjadi sangat dinamis. Tingginya aktivitas dalam media sosial tersebut bahkan dapat berdampak pada pergerakan sosial dan perubahan politik di Indonesia (Nugroho, 2012; Lim, 2014).

Besarnya jumlah pengguna media sosial dan iklim demokrasi yang memberikan 
kebebasan berpendapat di Indonesia menjadikan aktivitas di media sosial demikian tinggi, cepat, dan seketika (real time). Tinggi dan besarnya aktivitas di media sosial tersebut tidak jarang kemudian memicu dan memacu ketegangan antara pengguna media sosial, seperti twitter dan facebook. Ketegangan tersebut digerakkan oleh kerja aktor yang dikenal sebagai opinion maker di media sosial. Opinion maker di media sosial berdiri sendiri namun saling terhubung satu sama lainnya. Gagasan tentang opinin maker mengacu pada konsep opinion leader dalam teori TwoStep Flow Comunication yang diajukan oleh Ellihu Katz dan Paul Lazarsfeld (Katz, 1957) untuk menggambarkan transfer informasi atau pesan melalui dua tahap. Tahap pertama, infomasi atau pesan yang menyebar melalui media massa diterima oleh seorang opinion leader yang memiliki akses terhadap sumber informasi atau pesan tersebut. Tahap kedua, informasi atau pesan yang diterima seorang opinion leader tersebut kemudian menyebar kepada masyarakat.

Dalam pengertian yang lebih luas dalam konteks media sosial saat ini,istilah opinion leader kemudian dapat dipahami sebagai orang yang memberi pengaruh atau dapat mempengaruhi pengikut mereka (followers) terhadap suatu isu tertentu yang sedang diperbincangan di media sosial. Dalam konteks yang telah berubah tersebut, seorang opinion leader bukan lagi sebagai pihak yang menyampaikan opini mereka karena memiliki akses pada sejumlah sumber informasi, tetapi dapat beralih menjadi opinion maker. Konteks media sosial yang sangat dinamis memberi kemungkinan bagi siapa saja menjadi seseorang yang mendesain opini yang diinginkannya.

Potret media sosial seperti itu disebut Klein (dalam Porta, 2013) sebagai 'web like image'. Aktivitas di media sosial seperti jaring laba-laba. Dalam jaringan tersebut ada bagian inti (pusat jaringan) sebagai pusat seluruh aktivitas media sosial. Pusat inti jaringan (hubs) tersebut dihubungkan oleh seorang aktor sebagai perantara (bridge). Aktor perantara ini menyebarkannya pada aktor jaringan lainnya. Borgatti dan Lopez-Kidwell (2011) menilai, aktor yang berperan sebagai perantara dalam suatu ikatan yang lemah dengan aktor lainnya. Walau lemah, namun mereka intensif berhubungan di media sosial.

Aktor sebagai perantara yang membuat aktivitas di media sosial dinamis tersebut saling menstimulasi aktor lainnya. Saling stimulasi antar aktor dalam satu kelompok kepentingan dengan aktor lainnnya yang melakukan hal serupa pada kelompok yang berbeda pada titik tertentu dapat memicu perang siber (cyber war). Perang siber (cyber war) dapat dipahami sebagai suatu situasi adanya proses penyangkalan, pengrusakan, berbagai modifikasi informasi dengan tujuan yang ditentukan si pengirim, seperti penyerangan, manipulasi, serangan balik, melalui berbagai cara cyber, psikologis, yang akan mempengaruhi/mengganggu pihak musuh dalam aspek infrastruktur dan pengambilan keputusan. Selain itu bisa dengan cara penipuan, pengingkaran, penyangkalan, disinformasi, termasuk yang bersifat ancaman (halus maupun kasar) atas informasi aktual yang telah disampaikan oleh pihak pemerintah misalnya atau pihak 
lain yang relevan (Hutomo, 2016). Berbeda dengan perang konvensional, perang siber tidak membutuhkan tempat (place), tetapi membutuhkan ruang (space) (Rid, 2013).

Namun demikian, menurut Lane (2003) 'perang informasi' di media sosial masih dalam tataran semantik. Mereka menyebutnya "involves engaging and undermining the discursive norms and realities of the systems as a whole". Berbagai konten yang diproduksi aktor media sosial sengaja diciptakan untuk menghancurkan wacana normatif dan realitas sistem kekuasaan saatini sebagai suatu kesatuan. Hal ini mirip dengan pengertian dalam US Army Field Manual yang mendefinisikan perang informasi sebagai tindakan yang diambil untuk mencapai superioritas informasi, dengan mensikapi informasi yang bermusuhan, proses berbasis informasi dan sistem informasi, dan mempertahankan informasi yang dimiliki, proses-proses informasi dan sistem-sistem informasi (Baklarz and Forno, 1999).

Latar belakang, konteks dan beberapa hasil kajian tersebut mendorong penelitian tentang perang siber di media sosial dan polarisasi netizen di Indonesia penting untuk dilakukan. Hal tersebut dimaksudkan agar khalayak media sosial yang lazim disebut sebagai netizen memiliki literasi dalam aktivitas mereka di media sosial. Hal ini menjadi penting untuk diteliti agar perang status di media sosial antara netizen tidak terjerumus pada penyampaian berbabagi status ujaran penuh kebencian.

\section{Metode Penelitian}

Penelitian ini menggunakan metode kualitatif untuk mencari pengetahuan atau pemahaman berbagai relasi yang saling terkait di balik suatu realitas pada era media sosial. Data yang diperlukan dalam penelitian ini adalah data yang bersifat kualitatif sebagai data primer. Peneliti akan lebih banyak mengarahkan analisis terhadap data kualitatif karena menyangkut aktivitas dan dinamika yang terjadi dalam suatu lingkup kebudayaan virtual. Penelitian ini tidak dimaksudkan untuk memperoleh external validity, melainkan lebih bertujuan untuk memperoleh pemahaman mengenai suatu realitas dalam konteksnya yang spesifik. Hal ini memberi keluasan dan keluwesan peneliti memberi tafsir dan analisis terhadap data yang diperoleh.

Data dikumpulkan melalui wawancara mendalam pada narasumber penelitian dan studi literatur. Mengacu pada Wimmer dan Dominick (2014), wawancara mendalam dimaksudkan untuk memberikan latar belakang mendetil tentang alasan mengapa narasumber memberi jawaban spesifik. Narasumber yang diwawancarai adalah aktivis media sosial yang bertindak sebagai opinion maker.Narasumber dipilih berdasarkan kelayakan dan ketersediaan akses peneliti terhadap narasumber (Stokes, 2006) dan kompetensi mereka, bukan atas representativeness (keterwakilan) (Bernard, 1998). Peneliti memiliki kepentingan pada siapa yang paling mungkin memberikan data dan apakah data yang mereka berikan sudah memadai atau belum untuk menjelaskan permasalahan yang sedang diteliti.

Selain menggunakan teknik wawancara untuk mengumpulkan data, penelitian ini juga menggunakan teknik studi dokumentasi dan 
literatur. Penggunaan dokumentasi sematamata untuk mendukung perolehan data yang berada dan tersebar dalam realitas yang ada di di media sosial. Data dokumentasi yang dimaksud dalam penelitian ini adalah mencari, menemukan dan memeriksa kembali status di media sosial yang relevan dari beberapa akun twitter netizen. Data ini penting karena dokumentasi tersebut merupakan sumber informasi yang lestari, meskipun ia tidak berlaku lagi. Selain itu, dokumentasi tersebut merupakan bukti yang dapat dijadikan dasar mempertahankan diri terhadap tuduhan atau kekeliruan interpretasi. Dan dokumen merupakan sumber data yang alami yang bukan hanya muncul dalam konteksnya, tetapi juga menjelaskan konteks itu sendiri.

Data-data tersebut selanjutnya diproses dalam sejumlah kategori yang mengarah pada upaya generalisasi untuk kemudian disajikan secara interpretative dan descriptive. Data yang terkumpul dikompilasi secara tematik berdasarkan informasi yang diperoleh. Kompilasi data dilakukan melalui pemilahan yang relevan dengan masalah penelitian. Bagian akhir dari metode analisis data adalah mencari dan menemukan interelasi dan koherensi data dari lapangan yang digali dari sumber penelitian berupa pandanganpandangan narasumber yang diwawancarai. Data yang terkumpul dikompilasi secara tematik berdasarkan informasi yang diperoleh. Kompilasi data dilakukan melalui pemilahan yang relevan dengan masalah penelitian. Pada tahap ini, peneliti akan melakukan pendalaman dengan cara masuk ke alam kesadaran subyek (contemplating the content of mind) berupa mengingat (remembering), meresapi (perceiving), dan mengingini (desiring).

\section{Hasil Penelitian dan Pembahasan}

\section{Demokrasi Virtual dan Hasrat Menyam- paikan Ujaran Kebencian}

Dalam sistem demokrasi - karena penyelenggaraan negara bertumpu pada partisipasi publik-maka pemerintah (state) pada dasarnya memiliki peran sebagai wasit yang mengatur kehendak warga negara. Kehadiran negara melalui pemerintah yang dibentuk berdasarkan kehendak publik hanya mengatur individu sebagai warga negara dan kelompok yang berlomba-lomba untuk memaksimalkan kepentingan mereka. Dalam relasi dan posisi tersebut, media (baik media massa konvensional maupun media sosial) dapat berperan menjadi pembentuk opini publik. Sehingga dalam kehidupan media sosial saat ini, kekuatan daya tahan suatu negara dan politik sering diadu, diuji dan dipertentangan di media sosial oleh masyarakat online (netizen) (Fuchs and Trottier, 2015).

Konteks demokrasi tersebut turut mempengaruhi warga dalam menyampaikan pandanganmerekadimediasosial,khususnya twitter dalam menstimulasi kebencian. Dalam hal ini, terdapat dua karakteristik kunci yang menentukan. Karakter tersebut adalah bentuk spesifik dari berbagai jenis media sosial. Pertama, setiap bentuk yang spesifik tersebut memiliki kemampuan memobilisasi berbagai dukungan jika digunakan sesuai karakter spesifiknya. Twitter merupakan jenis media sosial yang paling memberi pengaruh terhadap perubahan politik melalui pembentukan opini publik karena memiliki fasilitas tanda pagar (hashtag). Hashtag tersebut memiliki tiga kekuatan sekaligus, melokalisir topik, memfokuskan topik dan memudahkan 
sistem pencarian berbasis internet. Kedua, karena berlangsung secara virtual dengan kapasitas kalimat yang terbatas, konten status dalam twitter memiliki kemampuan membangkitkan kemarahan netizen.

Berbagai konten yang mengandung ujaran kebencian dengan karakteristik media sosial yang dinamis tersebut menjadi perbincangan terbatas pada jenis media sosial lainnya seperti grup WhatsApp atau grup fecabook. Karena bersifat terbatas, percakapan sebelumnya yang mengandung ujaran kebencian mengabaikan etika, moral dan attitude di media sosial terbuka seperti twitter dan facebook, kembali diperbincangkan ulang dengan penuh kemarahan, mengabaikan etika, moral dan attitude. Sehingga, moral, etika dan attitude dapat pula mempengaruhi perbincangan media sosial atau di grup tertutup (James, 2014; McNeal and Holmes, 2016).

Kemarahan tersebut kemudian menjelma menjadi kerumunan virtual. Kerumunan virtual tersebut pada giliran dapat saling memicu dan mendorong produksi ujaran kebencian di media sosial. Ujaran kebencian (hate speech) merupakan bentuk penghinaan (Wolfson, 1997). Neu (2009) menjelaskan, sebagai penghinaan, ujaran kebencian juga digunakan untuk menunjukkan superioritas dan dominasi. Superioritas dan dominasi tersebut tidak berhubungan langsung dengan relasi mayoritas dan minoritas. Di media sosial, kelompok mayoritas tidak serta merta menjadi superior dan dominan terhadap minoritas. Di Indonesia, superioritas dan dominasi melalui ujaran kebencian di media sosial lebih memiliki relasi pada penguasaan akses pada pusat kekuasaan dan wacana.
Oleh sebab itu, menjelang pemilihan umum berbagai ujaran kebencian tersebut bisa meningkat, masif, gencar dan terbuka menjadi perbincangan yang ekstrim. Mengacu pada Pohjonen dan Udupa (2017), berbagai ujaran kebencian yang ekstrim dan tajam tidak hanya terjadi di Indonesia, tapi juga di India dan Ethopia. Di Indonesia, faktor sosial masyarakat yang suka berkerumun, berkumpul dan bergunjing membahas rumor atau isu tertentu menjadi salah satu faktor ramainya aktivitas di media sosial seperti twitter.

Menurut Informan 1, salah satu opinion maker di media sosial twitter, ujaran kebencian itu awalnya hanya ungkapan eforia kebebasan berbicara karena iklim demokrasi dalam kanal baru di media sosial. Ujaran kebencian tersebut dinilai efektif sebagai kampanye negatif pada pemilihan umum, kemudian digunakan sebagai teknik dalam perang siber.

"Sejak awal sekitar tahun 2007 sudah ada (penyampaian ujaran kebencian-Peneliti), tetapi tidak sistematis. Ujaran kebencian itu baru ada secara sistematis menjelang Pilkada DKI tahun 2011. Pada masa awal sekitar tahun 2007, pengguna media sosial belum bisa mengontrol dan belum paham bahwa ini kanal yang sangat bebas. Tapi saya melihat, (penggunaan ujaran kebencian-Peneliti) awalnya ada eforia, kemudian dipilih menjadi teknik perjuangan atau peperangan. Jadi alatnya adalah sosmed atau twitter, kemudian ada teknik agitasi dan provokasi yang dipakai pada tahun 2012 saat Pilkada DKI Jakarta. Kemudian peperangan tersebut mengeras pada tahun 2014 saat Pemilihan Presiden". (Informan 1, Januari 2017).

Informasi tersebut menunjukkan bahwa faktor politik menjadi menjadi salah arena virtual yang yang potensial mendorong seorang netizen menyampaikan ujaran kebencian melalui media sosial. Untuk me- 
ngaburkan identitas, netizen yang menebar kebencian menggunakan akun anonim. Keberadaan akun anonim yang digunakan untuk kepentingan politik tertentu akan menjelaskan bahwa dunia virtual adalah dunia yang penuh dengan kepalsuan dan tipu daya. Tipu daya dalam media sosial, terlebih-lebih pada momentum politik, sering dilakukan melalui akun buzzer. Kelompok ini sangat lihai dan mahir mengelola kebohongan dan berbagai kebodohan sebagai isu publik melalui media sosial. Tanpa disadari, keriuhan dan aktivitas massif para buzzer dan bot politik tersebut sesungguhnya telah mencederai demokrasi digital. Perdebatan dangkal antar buzzer yang masing-masing menggunakan teknik penyebaran ujaran kebencian bukan saja merugikan publik, tetapi mengancam masa depan demokrasi yang mengarah pada demokrasi penuh caci maki.

Istilah buzzer mengacu pada konsep buzz marketing, yaitu aktivitas atau kegiatan pemasaran suatu produk pada saluran media komunikasi untuk menciptakan gangguan. Gangguan tersebut ditujukan pada kompetitor untuk menarik target audience. Buzzer inilah yang akan melempar isu di media sosial, terutama twitter, sehingga menjadi perbincangan luas khalayak (viral). Agar sebuah tweet menjadi viral, akun twitter yang menjadi buzzer didukung oleh puluhan bahkan ratusan akun robot (dikenal dengan akun bot, yang dibuat untuk pekerjaan otomatis seperti retweet). Atau sesama akun twitter yang menjadi buzzer tersebut saling sahut menyahut tentang suatu isu yang sedang diperbincangkan. Akun buzzer menjadi aktor penting dalam menyebar luaskan kebencian untuk kepentingan politik.

Golongan buzzer politik ini secara sempit membela habis-habisan kepentingan politiknya, dan mencerca sepuas-puasnya yang menjadi lawan politik mereka. Penyampaian berbagai ujaran kebencian menjadi hasrat politik. Karena kepentingan politik tersebut terpersonifikasi pada calon Gubernur, misalnya, maka pembelaan dan perlawanan yang terjadi juga bersifat personal. Saling cerca antar buzzer politik tersebut membanjiri dan mengotori lini masa (timeline) media sosial. Perdebatan menjadi dangkal karena penuh amarah, caci, maki dan cercaan. Perdebatan jauh dari isu atau informasi yang mencerahkan publik karena yang dibicarakan bukan visi, misi, prestasi atau rekam jejak calon Gubernur yang diperjuangkan.

Aktivitas di media sosial yang buruk tersebut kemudian memunculkan informasi hoax. Mengacu pada Hoaxes karya klasik Curtis D. MacDougall (1985), hoax dapat dipahami sebagai ketidakbenaran yang diproduksi secara sengaja untuk menyamarkan suatu kebenaran. Hoax dalam pengertian ini menjadi akan sangat ditentukan oleh motif dan maksud dari pembuatnya. Oleh sebab itu pula, menjadi agak tidak jelas dan kabur antara kebohongan, kecurangan, kejahatan, hoax dan kebenaran. Penyebaranujaran kebencian dan hoax di media sosial memungkinkan lebih cepat menjalar dan menyebar secara luas karena karakteristik media sosial yang spesifik. Karakter spesifik media sosial tersebut adalah (Nasrullah, 2014): 
1) Intertextuality, artinya setiap teks dan beberapa teks lainnya dapat saling tertaut dan 'berbicara'. Oleh sebab itu, satu teks terkadang hanya dapat 'dibaca' dan dipahami maknanya bila membaca terlebih dahulu teks lainnya. Lebih jauh, jaringan antar teks tersebut dapat menciptakan konteks.

2) Nonlinearity, artinya setiap pergerakan pembicaraan tidak dapat diprediksi secara lurus dan linear. Satu topik pembicaraan dapat saja berkembang dan melahirkan topik baru lainnya.

3) Blurring the reader/writer distinction, artinya ada pembeda yang kabur antara pembaca dan penulis. Dapat saja seorang netizen awalnya sebagai konsumen informasi. Namun informasi tersebut dikemas ulang kemudian didistribusikan kembali menjadi konten baru. Pada saat bersamaan reproduksi informasi tersebut menjadi pembatas yang halus antara konsumen dan produsen informasi.

4) Multimedianess, artinya media sosial bersifat konvergensi yang dapat memuat teks, audio, video dan sebagainya.

5) No Gatekeeper, artinya dalam media sosial tidak ada 'penjaga gawang' yang berfungsi menyeleksi infomasi yang masuk dan keluar di media sosial sebagaimana yang terjadi pada media mainstream.

6) Ephemerality, artinya teks di media sosial bersifat tidak stabil. Atas kehendak sendiri, suatu teks di media sosial dapat dihapus baik disengaja maupun tidak disengaja.

Dengan karakteristik tersebut, aktivitas di media sosial memberi kemungkinan pada setiap orang untuk saling berbagi informasi secara luas atau terbatas pada orang yang dikehendakinya. Melalui karakteristik salurannya, media sosial dapat mengidentifikasi arah pesannya (Kent, 2010) atau menggunakan alat khusus seperti Facebook atau Twitter untuk menunjukkan model interaksinya (Howard, and Parks, 2012). Interaksi dan penyebaran informasi tersebut dapat diperoleh dariberbagai sumber di internet atau memproduksinya sendiri. Aktivitas tersebut menjadi meningkat lebih dinamis karena Indonesia merupakan negara demokrasi yang memberi keleluasaan bagi setiap orang untuk menyampaikan pendapat mereka di media sosial. Dengan demikian secara tidak langsung, netizen dan media soal dapat berperan sebagai agen sosial perubahan politik (Gordon, 2017).

Aktivitas di media sosial dengan berbagai situasi dan faktor tersebut diperburuk dengan lemahnya self control dari netizen. Studi Suller (2004) menjelaskan bagaimana orang dapat menyampaikan sesuatu di dunia media sosial yang dalam kehidupan nyata sehari-hari tidak mungkin mereka lakukan. Fenomena tersebut dijelaskannya sebagai online disenhibition effect. Hal ini dampak karena tidak adanya kendali pada pengguna media sosial untuk menyampaikan secara bebas apa saja yang ingin mereka sampaikan.

\section{Tiga Gelombang Perang Siber dan Polarisasi Netizen}

Kehendak khalayak yang menolak kebebasan mereka dibatasi dalam menyampaikan pendapat melalui media sosial, seperti membuka ruang bagi siapa saja untuk beropini di media sosial. Faktor 
akses penguasaan teknologi dan pengetahuan terhadap pengaruh sosial politik dari media sosial merupakan jejak awal ujaran kebencian tersebut bermula. Berbagai ujaran kebencian yang tersebar pada masa awal media sosial masuk ke Indonesia tersebut dapat digambarkan dalam sebuah perang siber di media sosial. Pada jenis media sosial twitter, gambaran tersebut dapat berupa twitwar atau perang status di twiter.

Dalam konteks tersebut, twitwar merupakan bentuk perang siber yang paling keras dan nyata di media sosial. Di media sosial, sebuah peperangan tidak membutuhkan tempat, tidak mengenal waktu bahkan tidak mengenal dengan baik siapa pihak yang saling berperang (Rid, 2013). Media sosial tersebut masuk dalam kategori ruang siber karena merupakan jenis media yang dikembangkan berbasis internet. Dalam aktivitas politik, ruang di media sosial dan ruang fisik dalam kehidupan nyata memiliki hubungan saling tergantung (Lim, 2006). Perang siber dalam media sosial tersebut merupakan perjalanan yang sulit dirumuskan karena dinamisnya aktivitas di media sosial. Untuk memahami kerumitan tersebut penelitian ini memberi tiga fase gelombang perang siber berdasarkan dinamika yang terjadi di media sosial. Dinamika dan aktivitas di media sosial dalam tiga gelombang perang siber tersebut dapat digambarkan pada Gambar 1.

\section{Gelombang Pertama; Perang Apa Melawan Apa?}

Di Indonesia, pada masa awal penggunaan media sosial seperti twitter, twitwar, atau berbagai ujaran kebencian belum terpolarisasi dengan jelas merepresentasikan antar kelompok kepentingan. Namun demikian, penggunaan media sosial untuk kepentingan politik, sebagaimana di tempat lain, selalu terkonsep dan tersamar (Shirky, 2011). Aksi netizen yang menginginkan FPI (Front Pembela Islam) dibubarkan, karena dianggap sebagai salah satu sumber kekerasan di Indonesia merupakan peristiwa awal yang dapat dirujuk untuk menjelaskan polarisasi kelompok yang berpolemik dalam perang siber tersebut.

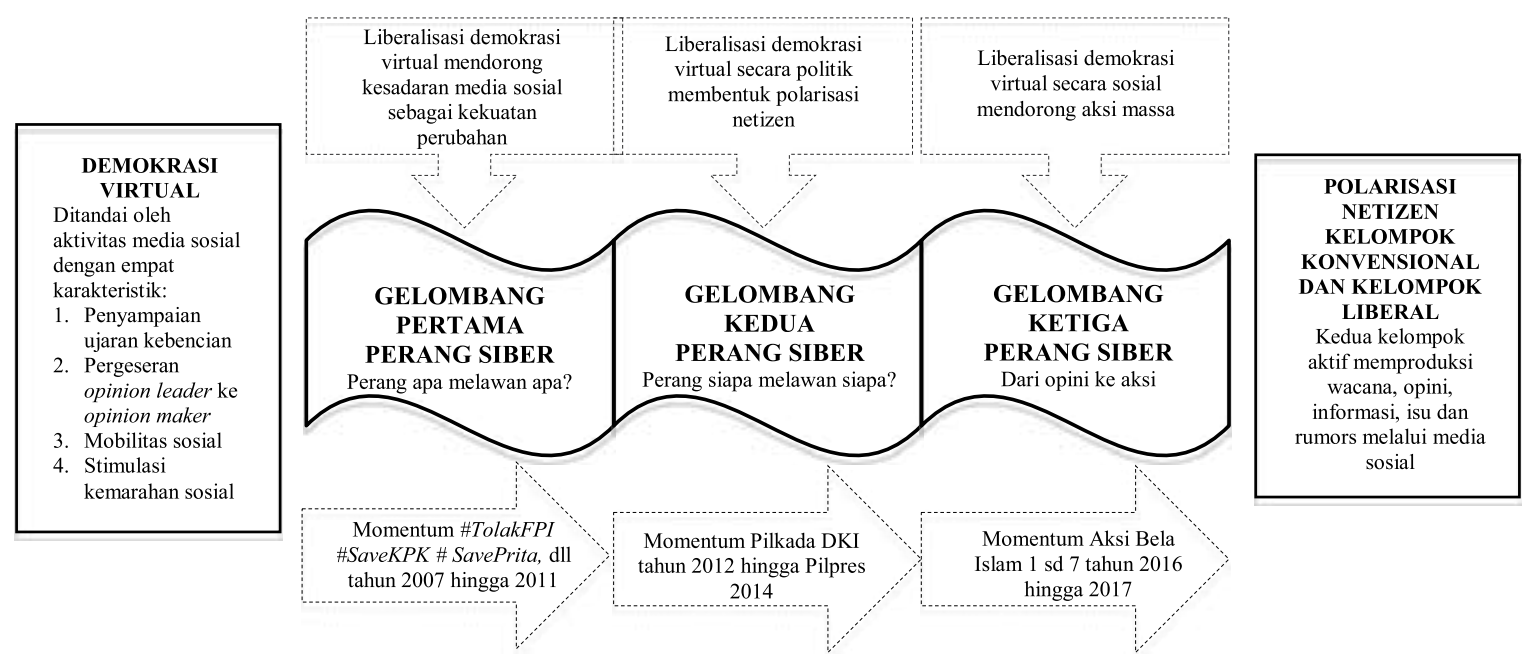

Gambar 1. Demokrasi Virtual dan Tiga Gelombang Perang Siber di Media Sosial Sumber: Diolah dari data penelitian 
Kendati FPI menyatakan mereka berjuang melawan kemungkaran, sejumlah pihak justru menilai FPI sebagai pihak yang jahat, sumber kekerasan dan melawan toleransi. Hal tersebut terjadi sejak tahun 2000 dan meningkat secara eskalatif hingga tahun 2007. Presiden Republik Indonesia, Soesilo Bambang Yudhoyono saat itu dinilai gagal mengambil tindakan. Kemudian sejumlah aktivis dan masyarakat biasa memutuskan untuk mengambil tindakan melalui media sosial. Untuk menggalang dukungan melalui media sosial dengan topik "Indonesia Tanpa FPI" dan tweets dengan hashtag \#IndonesiaTanpaFPI. Tidak cukup menggalang dukungan di media sosial, aksi juga dilakukan dengan cara turun ke jalan menuntut FPI dibubarkan (Nugroho and Syarief, 2012).

Kondisi seperti ini merupakan potret awal sebagai pengantar perang siber gelombang pertama. Suatu potret dimana ada sekelompok masyarakat yang sudah beradaptasi cukup baik dengan teknologi komunikasi berbasis internet. Kelompok ini juga memahami dengan baik manfaat dan kekuatan media sosial sebagai salah satu jalur yang ditempuh untuk memperjuangkan gagasan. Pada saat bersamaan, ada kelompok berbeda yang berada pada posisi sebaliknya. Kelompok yang belum mampu beradaptasi dengan cukup baik dengan teknologi komunikasi berbasis internet dan belum memahami dengan baik manfaat dan kekuatan media sosial dalam dinamika kehidupan politik.

Hingga kemudian memasuki tahun 2011, menjelang Pilkada DKI Jakarta saat itu, mulai terlihat ada polarisasi. Polarisasi kelompok tersebut tampak setelah tim pemenangan pasangan Joko Widodo (Jokowi) dan Basuki Tjahja Purnama (Ahok) membentuk JASMEV (Jokowi Ahok Social Media Volunteers) pada 12 Agustus 2012. Kehadiran JASMEV tidak terlepas dari trend global dunia yang mulai melirik kekuatan media sosial saat itu. Terpilihnya Barrack Obama sebagai Presiden AS pada tahun 2008 dapat dirujuk sebagai kemenangan politik, salah satunya karena memanfaatkan kekuatan media sosial. Media sosial saat itu diorganisir dengan baik untuk memobilisasi gerakan masyarakat yang mendukungnya (Shirky, 2011). Selain menggunakan websitemy.barrackobama. com, Obama juga memiliki lima belas situs media sosial untuk kampanye politik yang dilakukannya (Effing, and Huibers, 2011).

Kondisi tersebut mirip dengan dibentuknya JASMEV sebagai salah satu mesin kampanye pasangan Jokowi-Ahok pada masa Pilkada DKI Jakarta tahun 2012. Awalnya JASMEV merupakan kumpulan relawan yang mendukung pasangan JokowiAhok, seperti dituturkan koordinator JASMEV, Kartika Djoemadi (http://www. beritasatu.com/megapolitan/66145-seriburelawan-sosial-mediauntuk-jokowi-ahok. html):

"Tugas kami (JASMEV) adalah untuk menghimpun dan mengkoordinir para relawan di media sosial agar lebih efektif dan efisien dalam mendukung pasangan Jokowi dan Ahok dengan cara menyampaikan informasi yang positif dan elegan."

Kehadiran JASMEV ini dapat disebut kampanye politik pertama di Indonesia yang mengandalkan kekuatan relawan 
yang terorganisir melalui media sosial. Kekuatannya pada konsep relawan dan media sosial. Melalui berbagai saluran media sosial, secara on line para relawan tersebut saling terhubung satu sama lainnya. Kesalingterhubungan tersebut membentuk jaringan informasi yang luas, masif, real time dan terus menerus. Khalayak penggiat media sosial seperti dikepung oleh derasnya informasi tentang Jokowi-Ahok saat itu. Tujuan jaringan tersebut jelas tentu untuk memberi kesan positif pada pasangan Jokowi-Ahok yang mereka dukung. Selang sebulan setelah dibentuk, JASMEV mampu meraih 10 ribu relawan media sosial.

JASMEV menjadi alat yang efektif untuk melakukan marketing politik pasangan Jokowi-Ahok di media sosial. Sebagai alat politik, penggunaan media sosial dapat dibagi pada dua kelompok besar. Pertama cyber-optimists yangpercaya bahwa media sosial memiliki kemampuan untuk menghapus berbagai sekat interaksi antara publik dan politisi. Interaksi ini akan memacu transformasi baru yang lebih dinamis, cepat dan transparan. Kedua, cyberpesimist yang menilai media sosial hanya cukup membantu menguatkan sistem politik konvensional yang sudah berlangsung lama di tengah masyarakt. Kondisi ini tidak dapat memacu transformasi (Norris, 2003). Baik pandangan pertama atau pandangan kedua sama-sama tidak dapat menghindari kehadiran media sosial merupakan bagian dari modernisasi kampanye politik.

Relawan dan maksimalisasi media sosial menjadi kunci penting kemenangan pasangan Jokowi-Ahok pada Pilkada
DKI Jakarta tahun 2012. Di media sosial, aktivitas para relawan tersebut sangat membantu menyebarkan mention atau buzzer untuk Jokowi. Sebaran tersebut mencapai angka dua juta. Angka dua juta ini muncul dari lebih dari 900 ribu akun yang berbeda (uniqueusers) (http://www.tempo. co/read/news/2012/09/18/228430219/ PoliticaWave-Isu-SARA-TakLaku-diPutaran-Kedua).Selain bergerak di media sosial secara online, para relawan tersebut juga bergerak secara offline. Seluruh pergerakan online dan offline tersebut dimonitor dengan ketat melalui "War Room dan Data Center Relawan Jakarta Baru". Di ruang inilah dianalisis dan dikoordinasikan berbagai hal tentang kampanye, hingga sentimen yang menjalar di media sosial. "War Room dan Data Center Relawan Jakarta Baru" dipimpin oleh Hasan Nasbi yang juga merupakan Direktur Eksekutif Cyrus Network, konsultan politik Jokowi-Ahok. War Room tersebut memantau sebanyak 15 ribu relawan di lapangan dengan 706 koordinator dan 42 supervisor yang menyusun berbagai strategi perang mennggunakan media sosial (http://sorot.news.viva.co.id/news/ read/353339-rahasia-kemenangan-jokowi).

Menurut Informan 2, perang siber yang dijalankan oleh JASMEV memiliki pola tertentu. Pola perang wacana, opini, informasi, rumors dan isu di media siber tersebut bertumpu pada dua atau tiga orang yang bertindak sebagai opinion leader sekaligus opinion maker di media sosial, terutama twitter:

"Saya kenal dengan baik orang JASMEV, mere- 
ka teman saya pada masa lalu. Bahkan di media sosial saya sempat ribut dengan beberapa orang JASMEV. Pola serangannya (dalam perang siber-Peneliti), adalah fitnah atau membuat suatu isu, dilempar ke temannya yang lain di media sosial. Kemudian dihajar ramai-ramai dari kiri dan kanan (diviralkan-Peneliti) dengan menggunakan akun robot. Setelah ramai dibicarakan di media sosial nanti diliput oleh media. Pada sisi lain, mereka memilih agresif (dalam menebar fitnah dan isu-Peneliti), bukan berperan simpati (di media sosial-Peneliti). Kuncinya cuma ada pada dua atau tiga orang yang punya akun di media sosial. Kuncinya ada di mereka (sebagai Opinion Leader dan opinion maker-Peneliti), perhatikan apa yang mereka sampaikan.

Bahkan si Dede (akun@KangDede78-Peneliti) yang mengaku sebagai panglima perang Jokowi (di media sosial-Peneliti) sudah diingatkan, ini strategi perang yang salah. Tapi dia menilai ini sebuah perang, jadi harus sekasar mungkin. Sehingga mereka menyusun pola begini: 'Pertama, kalau kalah berdebat di sosmed (sosial media-Peneliti), buat dan kembali ke isu lain. Sehingga orang yang diajak berdebat akan melayani banyak isu dengan pasukan robot. Kedua, bully habis-habisan sampai orang tersebut trauma dan menutup akun. Itu sudah semacam SOP (Standar Operasional Prosedur-Peneliti). Namun saat ini pola serangan tersebut sangat mudah dibaca dan sangat mudah dibalik".(Informan 2, Januari 2017).

Informasi tersebut menunjukkan bahwa berbagai ujaran kebencian yang disebar melalui media sosial digunakan untuk kampanye dalam konteks politik pemilihan umum. Sementara menurut Informan 3, perang siber di media sosial memiliki pola yang sistematis sebagai strategi kampanye yang dilakukan oleh aktor dalam kelompok kepentingan politik yang sama.

"Opinion leader melempar isu, kemudian disambut oleh akun anonim atau sebaliknya. Kemudian diviralkan oleh akun robot dan dijadikan berita oleh media abal-abal. Setelah tampak agak ramai baru diterima dan diberitakan oleh media mainstream tanpa melakukan check dan recheck. Jika kemudian ada perlawanan, pihak yang melawan dibully. Istilahnya, kill the messenger. Satu lagi, itu semua disebar melalui media internal, yang bersifat tertutup dan terbatas seperti WahstApp. Jadi mulai dari produsen isu, penyebar dan lainnya itu satu kelompok dan berasal dari ruang kendali yang sama". (Informan 3, Fabruari 2017).
Dari ruang kendali inilah berbagai wacana, opini, informasi, isu dan rumors diolah, dianalisis dan dikendalikan. Pengorganisasian yang rapi menghasilkan kontrol terhadap wacana, opini, informasi, isu dan rumors di media sosial. Pada gilirannya, perang siber yang termanifestasikan saat Pilkada DKI Jakarta 2012 tersebut dapat dimenangkan. Keseluruhan kondisi berbagai perang wacana, opini, informasi, isu dan rumors di media sosial yang terkait Pilkada DKI Jakarta tahun 2012 itu dapat disebut sebagai perang siber gelombang pertama. Polarisasi kelompok yang terlibat dalam perang siber gelombang pertama tersebut berlanjut menjadi gelombang kedua perang siber pada saat Pilpres 2014.

Walau ada sejumlah perubahan, namun perang siber pada saat Pilpres tahun 2014 tetap merepresentasikan atau melibatkan kelompok yang terlibat dalam perang siber tahun 2012 . Perang siber pada gelombang kedua ini kembali dimenangkan oleh kelompok yang memenangkan perang siber pada gelombang pertama tahun 2012. Walau perang siber yang terjadi pada gelombang pertama ini tidak dapat diidentifikasi sebagai perang siapa melawan siapa, namun peperangan tersebut dapat diidentifikasi melalui perang opini atau wacana untuk memperoleh kekuasaan politik yang ingin diraih.

\section{Gelombang Kedua, Perang Siapa Melawan Siapa?}

Pada gelombang kedua ini berbagai fakta, wacana, opini, isu, dan rumors dalam arus informasi yang deras pada era media sosial yang dipaparkan tersebut dapat dilihat dari pokok atau substansi gagasan yang terkandung di dalamnya. Dengan 
memahami pokok atau substansi gagasannya dapat diidentifikasi dua kelompok. Kedua kelompok ini juga sulit untuk diidentifikasi dengan menggunakan kategori tertentu yang lebih spesifik, seperti kelompok liberal-fundamental, tradisional-modern, dan kategori identitas lainnya. Sebab, satu sisi ada aktor sebagai opinion maker media sosial yang dikenal berfikir liberal, tetapi justru berada pada kelompok fundamental. Pada sisi lain ada juga aktor yang yang identik pada kelompok fundamental berada pada posisi liberal.

Demikian pula halnya terdapat tokoh yang dikenal berada pada kelompok modern, tetapi berkumpul pada kelompok tradisional. Sebaliknya terdapat tokoh dari kelompok tradisional tetapi berada pada kelompok modern. Hal serupa juga berlaku untuk penggunaan kategori muslim dan non muslim, nasionalis dan sosialis. Sehingga benar-benar tidak mudah mengidentifikasi kelompok gerakan tersebut secara dikotomis hanya berdasarkan satu kategori identitas sosial, identitas keagamaan, atau ideologi yang diperjuangkan.

Namun bila menilik dari wacana, opini, isu dan rumors dalam arus informasi yang deras pada era media sosial yang dipaparkan dan pokok atau substansi gagasan yang terkandung di dalamnya, dua kelompok tersebut dapat dikategorikan sebagai kelompok konservatif dan kelompok liberal. Secara umum kelompok konservatif mengacu pada kelompok yang percaya pada sistem yang berlaku, atau mengikuti tradisi berfikir yang sudah mapan sebelumnya. Sebaliknya kelompok liberal mengacu pada kelompok yang meragukan sistem yang berlaku dan menolak tradisi berfikir yang sudah mapan sebelumnya. Pengelompokkan berdasarkan gagasan tersebut dapat diuji dengan melihat reaksi masing-masing kelompok di media sosial terhadap sejumlah isu sensitif yang pernah menjadi perbincangan publik di media sosial. Isu sensitif tersebut misalnya terkait soal isu LGBT (Lesbian, Gay, Biseksual dan Transgender), toleransi antar umat beragama, komunisme hingga isu tentang intervensi asing terhadap kedaulatan Indonesia.

Namun secara praktis, dalam praktek penyebaran wacana, opini, isu, dan rumors dalam arus informasi di media sosial pengelompokkan tersebut juga sulit untuk diidentifikasi. Kesulitan tersebut karena berbagai wacana, opini, isu dan rumors dalam arus informasi yang beredar di media sosial memiliki relasi dengan kepentingan politik praktis seperti yang dijelaskan pada perang siber gelombang pertama. Artinya, berbagai wacana, opini, isu, dan rumors dalam arus informasi di media sosial tersebut secara politik termanifestasikan dalam momentum politik pada saat Pilkada (terutama Pilkada DKI Jakarta tahun 2012) dan Pilpres tahun 2014. Sehingga berbagai wacana, opini, isu, isu, dan rumors dalam arus informasi di media sosial yang awalnya secara abstrak dapat diidentifikasi sebagai kelompok konservatif dan kelompok liberal secara politik termanifestasi menjadi kelompok yang terlibat mendukung pasangan politik yang berkompetisi di Pilkada DKI Jakarta tahun 2012 dan Pilpres tahun 2014. 
Pada gelombang pertama saat Pilkada DKI tahun 2012, untuk memudahkah analisis dan pembahasan sebut saja 'kelompok konservatif' mendukung pasangan incumbent Fauzi Bowo-Nachrawi Ramli yang kembali mengikuti Pilkada DKI saat itu. Sedangkan 'kelompok liberal' mendukung pasangan Joko Widodo (Jokowi)-Basuki Tjahaja Purnama (Ahok). Pada gelombang pertama tersebut, 'kelompok liberal' relatif lebih siap memasuki dan menjalankan operasi perang siber untuk menguasai dan memegang kendali opini di ruang virtual. Usaha itu disiapkan dengan matang melalui JASMEV. Sementara 'kelompok konservatif' tidak memiliki persiapan yang cukup baik, dalam pengertian pengorganisasian wacana, opini, informasi, isu dan rumors saat menghadapi perang siber di media sosial. Dengan demikian, pada gelombang pertama dapat dikatakan kemenangan pengorganisasian wacana, opini, informasi, isu dan rumors saat menghadapi perang siber di media sosial berhasil menghantarkan kemenangan Jokowi sebagai Gubernur DKI Jakarta.

Menurut Informan3, kemenangan kelompok liberal terhadap kelompok konservatif pada perang siber gelombang pertama dan kedua tersebut karena tiga faktor, yaitu pengorganisasian, pendanaan dan kesadaran berperang di media sosial. Tiga hal tersebut tidak dimiliki oleh kelompok konservatif.

"Sebenarnya kelompok konservatif jumlahnya cukup banyak, cuma tidak terorganisir dengan baik di media sosial. Selain itu, tidak ada donatur atau penyandang dana. Perang di media sosial-kan membutuhkan pendanaan juga. Dana tersebut yang membayari proyek buzzer di me- dia sosial. Sementara dari kelompok konservatif juga tidak menyadari bahwa orang (Kelompok liberal-Peneliti) sudah siap dengan cara berperang seperti ini. Sementara mereka (Kelompok liberal-Peneliti) banyak sekali opinion leader-nya. Opinion leader mereka sangat siap berperang bahkan bisa mengintimidasi di media sosial. Saya melihat ada ketakutan di kalangan konservatif di media sosial untuk speak out". (Informan 3, Fabruari 2017).

Selanjutnya pada gelombang kedua saat Pilpres tahun 2014, 'kelompok konservatif' mendukung pasangan Prabowo SubiantoHatta Rajasa. Sementara 'kelompok liberal' mendukung pasangan Joko Widodo-Jusuf Kalla. Pada gelombang kedua ini perang siber tidak bergeser. Perang wacana, opini, informasi, isu dan rumors masih di media sosial masih berlangsung dengan tetap melibatkan opinion maker pada perang siber tahun 2012. Hanya saja ada beberapa opinion maker di media sosial yang 'berpindah' kelompok. Terkait dengan opinion makeryang melakukan migrasi pada perang siber, Informan2 sebagai salah satu pelaku migrasi tersebut menilai faktor karakter sosok seseorang yang diperjuangkan dalam politik merupakan faktor yang menentukan dirinya melakukan migrasi dalam perang siber.

"Saya pendukung Jokowi tapi bukan pendukung Ahok. Satu sisi saya pro perubahan dan anti kemapanan, namun pada sisi lain ada konservatisme dalam diri saya. Saya tidak ingin anak saya punya figur atau idola yang kasar seperti itu (Ahok-Peneliti). Setiap orang dianggap musuh olehnya". (Informan 2, Januari 2017).

Selain itu terjadi perluasan dan penajaman perang siber dari perang siber sebelumnya pada tahun 2012. Hal yang paling menonjol dari peperangan siber gelombang kedua ini terletak pada pengrusakan karakter Joko Widodo (Jokowi) dan Prabowo Subianto sebagai calon Presiden Republik Indonesia 
yang mengikuti Pilpres saat itu. Pilpres 2014 kemudian dimenangkan oleh pasangan Joko Widodo dan Jusuf Kalla. Pada jarak dua tahun tersebut menuju perang siber tahun 2016, beberapa kekeliruan pemerintah sempat menjadi perbincangan dan materi hangat di media sosial. Percikan saling serang wacana, opini, informasi, isu dan rumors muncul beberapa kali dalam skala kecil karena berbagai kekeliruan yang dilakukan oleh pemerintah (http://www.republika.co.id/ berita/nasional/politik/15/06/06/npiash-inidaftar-kesalahan-fatal-jokowi-semasa-jadipresiden). Eskalasi percikan saling serang wacana, opini, informasi, isu dan rumors dalam skala kecil tersebut kemudian meningkat pesat karena beberapa kebijakan Ahok sebagai Gubernur DKI Jakarta dinilai merugikan kelompok masyarakat muslim di Jakarta. Sebaliknya beberapa kebijakan tersebut dinilai menguntungkan kelompok lainnya. Beberapa dari kebijakan tersebut menjadi kontroversial dan menjadi perbincangan hangat di media sosial.

Hingga pada tanggal 27 September 2016, Basuki Tjahja Purnama atau Ahok sebagai Gubernur DKI Jakarta berpidato saat melakukan kunjungan kerja di pulau Pramuka, Kepulauan Seribu. Pidato Ahok ini kemudian dianggap sebagai menghina Al-Qur'an, kitab suci umat Islam.Mengacu pada laporan BBC Indonesia, berikut bagian petikan pidato Ahok yang akhirnya menimbulkan kontroversi tersebut (http://www.bbc.com/indonesia/ indonesia-37996601):

"Kan bisa saja dalam hati kecil Bapak Ibu, nggak pilih saya karena dibohongi (orang) pakai Surat Al Maidah 51 macam-macam itu. Itu hak Bapak Ibu. Kalau Bapak Ibu merasa nggak bisa pilih karena takut masuk neraka, dibodohin, begitu, oh nggak apa-apa, karena ini panggilan pribadi Bapak Ibu," katanya.

"Program ini (pemberian modal bagi budi daya kerapu) jalan saja. Jadi Bapak Ibu nggak usah merasa nggak enak karena nuraninya nggak bisa pilih Ahok," tambahnya.

Pidato Ahok yang dikenal sebagai insiden Al-Maidah 51 tersebut kemudian menjadi salah satu pemicu perang siber gelombang ketiga yang paling luas di media sosial Indonesia. Perang siber dalam bentuk saling mempengaruhi melalui wacana, opini, isu, gosip dan rumors di media sosial tersebut menstimulasi aksi demonstrasi besar yang dikenal dengan Aksi Bela Islam.Aksi Bela Islam sebanyak tujuh kali dengan dihadiri jutaan peserta. Namun Aksi Bela Islam III pada tanggal 2 Desember 2012 dikenal dengan Aksi 212 merupakan aksi terbesar karena dihadiri 5 juta lebih manusia dengan damai, tertib, aman dan bersih (http://www.republika.co.id/berita/ nasional/politik/16/12/05/ohou27415-menghitung-jumlah-peserta-aksi-212).

\section{Gelombang Ketiga Perang Siber; dari Opini ke Aksi}

Insiden Al-Maidah 51 dapat disebut sebagai faktor memicu terjadinya perang siber pada gelombang ketiga. Insiden tersebut menyatukan kelompok konservatif. Di media sosial kebangkitan kelompok konservatif ini sedemikian massif setelah Muslim Mega Cyber Army (MMCA) terbentuk (http://www.republika.co.id/ berita/jurnalismewarga/wacana/16/12/10/ ohx3sk385-muslim-megacyber-armyversus-ahok-cyber-army). Berbagai wacana, opini, informasi, isu dan rumors yang dianggap memojokkan umat Islam di media sosial dengan mudah dan cepat dipatahkan. 
Dibanding JASMEV yang terorganisir dan mendapat sokongan dana, MMCA bergerak tidak terorganisir, tanpa garis komando, karena itu tidak dapat diidentifikasi tapi mampu bekerja dengan efektif mematahkan serangan wacana, opini, informasi, isu dan rumors yang memojokkan Islam atau umat muslim di media sosial.

Perang siber di media sosial pada gelombang ketiga ini lebih dinamis, cepat, masif melalui pengendalian opini yang seimbang. Namun hal menonjol yang paling membedakan perang siber gelombang ketiga dengan gelombang pertama dan kedua adalah dampak media sosial terhadap gerakan massa. Menurut Informan 1, media sosial memberi pengaruh yang cukup besar pada gerakan Aksi Bela Islam.

"Saat ini banyak orang tidak lagi begitu mempercayai media mainstream atau media konvensional. Sehingga mencari informasi dari media sosial. Di media sosial mereka lihat teman yang mereka kenal baik ikut Aksi Bela Islam, ini yang salah satu hal yang membikin mereka ikut terpengaruh memgikuti aksi massa turun ke jalan”.(Informan 1, Januari 2017).

Perang siber gelombang ketiga ini semakin bertambah dinamis setelah sejumlah tokoh agama ikut terlibat sebagai opinion maker di media sosial. Sejumlah ulama seperti Habib Rizieq pemilik akun @syihabrizieq (sebelum ditutup)(https://news.detik. com/berita/d-3397160/akun-habib-rizieqdan-dpp-fpi-di-suspend-ini-penjelasantwitter).Abdullah Gymnastiar pemilik akun @aagym atau Tengku Zulkarnain pemilik akun@ustadtengku dalam kapasitas yang berbeda ikut aktif terlibat dalam perang wacana, opini, informasi, isu dan rumors di media sosial. Aktivitas agamawan di media sosial tersebut mendorong aksi massa yang dikenal dengan Aksi Bela Islam (ABI). Aksi ini bahkan dilakukan berlarut hingga sebanyak tujuh kali yaitu pada tanggal 14 Oktober 2016 (ABI I), 4 November 2016 (Aksi 411/ ABI II), dan 2 Desember 2016 (Aksi 212/ ABI III). Menyusul aksi berikutnya tanggal 11 Februari 2017 (Aksi 112/ABI IV), 21 Februari 2017 (Aksi 212/ABI V), 31 Maret 2017 (Aksi 313/ABI VI) dan 5 Mei 2017 (Aksi 505/ABI VII).

Keterlibatan para ulama atau agamawan dalam media sosial tersebut dapat dimaknai sebagai penyeimbang informasi. Realitas virtual di media sosial yang riuh dan penuh dengan wacana, opini, informasi, isu dan rumors tentang hal apa saja dapat membingungkan khalayak. Pada situasi tersebut, karakter seorang pengguna media sosial menjadi turut menentukan kebersihan dan kejernihan informasi. Dalam kapasitasnya sebagai agamawan, seorang Kiyai, Habib atau Ustad dapat menjadi penyaring informasi yang bersih dan jernih. Walau pada beberapa hal dapat memicu sentimen identitas, terutama bila status agamawan di media sosial tersebut terkait dengan praktek politik identitas.

\section{Simpulan}

Awalnya, kebebasan menyampaikan pendapat melalui media sosial dalam suatu iklim negara demokrasi digunakan oleh netizen sebagai fungsi kontrol sosial. Tanpa terkecuali kontrol sosial tersebut juga ditujukan pada aktivitas kelompok agama yang dinilai mengganggu ketertiban sosial. Pada masa awal tersebut, fungsi kontrol media sosial dikendalikan oleh kelompok netizen yang memiliki akses pada teknologi 
komunikasi berbasis internet. Berbagai kebebasan dalam iklim demokarasi tersebut menstimulasi hasrat netizen untuk menyampaikan ujaran kebencian.

Selanjutnya, berbagai ujaran kebencian dalam aktivitas di media sosial tersebut semakin tajam saat memasuki masa kampanye Pilkada DKI tahun 2012. Pada fase ini, berbagai ujaran kebencian tersebut efektif digunakan sebagai kampanye negatif. Berbagai ujaran kebencian tersebut beredar dan menyebar demikian cepat di media sosial sehingga menimbulkan perang status di twitter (twitwar). Twitwar tersebut berlangsung dengan cepat, sehingga tidak ada jarak (tenggat) waktu bagi netizen untuk memberi koreksi atau menilai kebenarannya. Berbagai kondisi tersebut kemudian membentuk polarisasi netizen di media sosial. Polarisasi tersebut dapat diidentifikasi sebagai kelompok konservatif dan kelompok liberal. Kedua kelompok tersebut aktif memproduksi wacana, opini, informasi, isu dan rumors melalui media sosial.

Penelitian ini secara teoritik memberi implikasi pada perubahan atau pergeseran konsep opinion leader pada teori two step communication yang berkembang dalam tradisi media massa konvensional kepada opinion maker yang berkembang dalam tradisi media baru seperti media sosial. Pergeseran konsep teoritik ini dapat digunakan oleh penelitian dalam lingkup media sosial berikutnya. Konsep opinion maker dalam tradisi media baru yang muncul saat ini memungkinkan siapa saja secara anonim menjadi opinion leader. Pergeseran konsep teoritik tersebut tidak dapat dilepaskan dari konteks kemajuan teknologi komunikasi dalam memproduksi dan mendistribusikan pesan atau informasi.

\section{Daftar Pustaka}

APJII: Infografis Panetrasi dan Prilaku Pengguna Internet di Indonesia. (2016). Tersedia dari: https://www. apjii.or.id/content/read/39/264/ Survei-Internet-APJII-2016.

Baklarz, R. and Forno, R. (1999). The Art of Information Warfare; Insight into the Knowledge Warrior Philosophy. Parkland : UniversalPublishers.

Bernard, H. R. (1998). Research Methods in Anthropology: Qualitative and Quantitative Approaches. Walnut Creek: AltaMira Press.

Borgatti, S.P. and Kidwell, V.L (2011). Network Theory. Dalam John Scott and Peter J. Carrington (Ed), The SAGE Handbook of Social Network Analysis (h. 167-179). London; Thousand Oaks, Calif. : SAGE.

Effing, R. and Huibers, T. (2011). Social Media and Political Particiption: Are Facebook, Twitter and Youtube Democratizing Our Political Systems? Dalam Efthimios Tambouris, Ann Macintosh, and Hans de Bruijn (Eds.), Electronic Participation(h. 25-35). Berlin : Heidelberg.

Fuchs, C. and Trottier, D. (2015). Social Media, Politics and the State: Protest, Revolutions, Riots, Crime and Policing in the Age of Facebook, Twitter and Youtube. New York : Routledge.

Gordon, S. (2017). Online Communities as Agents of Change and Social Movements. Harshey : Information Science Reference.

Howard, P. N. and Parks, M. R. (2012). Social Media and Political Change: Capacity, Constraint, and Consequence. Journal of Communication, 62, 359-362. 
Hutomo, Setio Budi H. (2016). Perang Informasi dalam Dunia Militer dan Bisnis. Dalam Iswandi Syahputra (Eds), Perang Semesta dalam Kajian Budaya dan Media (h. 91103). Bandung : Simbioasa Rekatama Media.

James, C. (2014). Disconnected: Youth, New Media, and the Ethics Gap. Cambridge : The MIT Press.

Katz, E. (1957). The Two Step Flow of Communication: An Up to Date Report on an Hypothesis. Diperoleh dari (http://poq. oxfordjournals.org/content/21/1/61).

Kent, M.L. (2010). Directions in Social Media for Professional and Scholars. Dalam R L Heath (Eds), Handbook of Public Realitions (h. 643-656).Thousand Oaks : Sage.

Khang, H., Ki, E., and Ye, L,. (2012) Socialmedia Research in Advertising, Communication, Marketing and Public Relations, 19972010.Journalism and Mass Communication Quarterly,89 (2), 279-298.

Lane, J. (2003). Digital Zapatista.TDR, 47 (2), 129-144.

Lim, M. (2014). Many Clicks but Little Sticks: Social Media Activism in Indonesia.Journal of Contemporary Asia, 43 (4), 636-657.

--------(2006). Cyber-Urban Activism and the Political Change in Indonesia. Eastbound, 1(1), 1-19.

Macdougall, C. D. (1985). Hoaxes. New York : Ace Books.

McNeal S. R. and Holmes, J. W. (2016). Social Media, Participation, and Attitudes. Dalam Igor Vobič, Tomaž Deželan.(R) evolutionizing Political Communication Through Social Media (h. 1-21).Hershey, USA : Publisher: IGI Global.

Nasrullah, R. (2014). Teori dan Riset Media Siber (Cybermedia). Jakarta : Kencana.

Neu, J. (2009). Sticks and Stones: The Philosophy of Insult. New York: Oxford University Press.
Norris, P. (2003). Preaching to the Converted? Pluralism, Participation and Party WebSites.Party Politics Journal, 9 (1), 21-45.

Nugroho, Y. and Syarief, S. S. (2012). Beyond Click-Activism? New Media and Political Processes in Contemporary Indonesia. Jakarta : Friedrich Ebert Stiftung.

Pohjonen, M. and Udupa, S. (2017). Extreme Speech Online: A Anthropological Critique of Hate Speech Debates, International Journal of Communication, 11, 1173-1191.

Porta, D. D. (2013). Can Democracy be Daved? Participation, Deliberation, and Social Movement. Cambridge, UK: Polity Press.

Prabowo, A. dan Arofah, K. 2017).Media Sosial Instagram sebagai Sarana Sosialisasi Kebijakan Penyiaran Digital. Jurnal ASPIKOM, 3(2), 256-269.

Rid, Thomas. (2013). Cyber War will not Take Place.London: Hurst/Oxford Press.

Shirky, C. (2011). The Political Power of Social Media. Foreign Affairs, 90 (1), 28-41.

Simangunsong, B. A. (2017).Interaksi Antarmanusia Melalui Media Sosial FacebookMengenai Topik Keagamaan. Jurnal ASPIKOM, 3(1), 65-76.

Stokes, J. (2006). How to Do Media and Cultural Studies. London : Sage.

Suler, J. (2004). The Online Disinhibition Effect. Cyberpsychology and Behavior, 7 (3), 321-325.

Weeks, B.E. and Holbert, R.L.(2013). Predicting Dissemination of Newsc Content in Social Media: A Focus on Reception, Friending and Partisanship. Journalism and Mass Communication Quaterly, 90 (2), 12.

Wimmer, R. D. and Dominick, J. R. (2014). Mass Media Research an Introduction. Wadsworth, Cengage Learning.

Wolfson, N. (1997). Hate Speech, Sex Speech, Free Speech.Connecticut: Praeger Publishers. 
Berita Online:

Akun Habib Rizieq dan DPP FPI di Suspend, Ini Penjelasan Twitter, tersedia di (https:// news.detik.com/berita/d-3397160/akunhabib-rizieq-dan-dpp-fpi-di-suspend-inipenjelasan-twitter) Diakses pada $27 \mathrm{Mei}$ 2017.

Ini Daftar Kesalahan Fatal Jokowi Semasa Jadi Presiden, tersedia di (http:// www.republika.co.id/berita/nasional/ politik/15/06/06/npiash-ini-daftarkesalahan-fatal-jokowi-semasa-jadipresiden) Diakses pada 26 Mei 2017.

Menghitung Jumlah Peserta Aksi 212, tersedia di (http://www.republika.co.id/berita/ nasional/politik/16/12/05/ohou27415menghitung-jumlah-peserta-aksi-212) Diakses pada 27 Mei 2017.

Muslim Mega Cyber Army versus Ahok Cyber Army, tersedia di (http://www. republika.co.id/berita/jurnalismewarga/ wacana/16/12/10/ohx3sk385-muslimmegacyber-army-versus-ahok-cyberarmy)Diakses pada 27 Mei 2017.
Pidato di Kepulauan Seribu dan Hari-hari hingga Ahok menjadi Tersangka, tersedia di (http://www.bbc.com/indonesia/ indonesia-37996601)Diakses pada 27 Mei 2017.

PoliticaWave: Isu SARA Tak Laku di Putaran Kedua, tersedia di (https://m.tempo. co/read/news/2012/09/18/228430219/ politicawave-isu-sara-tak-laku-diputaran-kedua) Diakses pada $26 \mathrm{Mei}$ 2017.

Rahasia Kemenangan Jokowi Membangun "pusat syaraf". Merakyat dengan 15 ribu relawan, tersedia di (http://sorot. news.viva.co.id/news/read/353339rahasia-kemenangan-jokowi) Diakses pada 26 Mei 2017.

Seribu Relawan Sosial Media untuk JokowiAhok, tersedia di (http://www.beritasatu. com/megapolitan/66145-seriburelawan-sosial-media-untuk-jokowiahok.html) Diakses pada 26 Mei 2017. 